\title{
Molecular Characterization of $\beta$-Lactamase Producing Genes and Integrons in Diarrheagenic Escherichia Coli From Diarrheal Children Less Than Five Years of Age in Ouagadougou, Burkina Faso.
}

Rene Dembele ( $\nabla$ simavedemb@gmail.com )

Université de Dedougou https://orcid.org/0000-0002-9282-8555

Wendpoulomdé A.D. Kaboré

Université Joseph Ki-Zerbo: Universite Joseph Ki-Zerbo

Issiaka Soulama

Centre National de Recherche et de Formation sur le Paludisme

Oumar Traoré

Université de Dedougou

Nafissatou Ouédraogo

Université de Dedougou

Ali Konaté

Université Joseph Ki-Zerbo: Universite Joseph Ki-Zerbo

Nathalie K Guessennd

Institut Pasteur d'Abidjan

David Coulibaly N'Golo

Institut Pasteur d'Abidjan

Antoine Sanou

Centre National de Formation et de Recherche sur le Paludisme

Samuel Serme

Centre National de Recherche et de Formation sur le Paludisme

Soumanaba Zongo

Centre National de Recherche et de Formation sur le Paludisme

Emmanuel Sampo

Hopital de Schiphra

Alfred S. Traoré

Université Joseph Ki-Zerbo: Universite Joseph Ki-Zerbo

Amy Gassama-Sow

Institut Pasteur de Dakar

Nicolas Barro

Université Joseph Ki-Zerbo: Universite Joseph Ki-Zerbo

\section{Research}

Keywords: Diarrheagenic E. coli, Antimicrobial resistance, ESBL, Integron, Burkina Faso.

Posted Date: June 28th, 2021

DOI: https://doi.org/10.21203/rs.3.rs-628039/v1

License: @ (i) This work is licensed under a Creative Commons Attribution 4.0 International License. Read Full License 


\section{Abstract \\ Background}

The aim of this study was to determine the resistance of diarrheagenic Escherichia coli strains to $\beta$-lactams antibiotics and to perform the molecular characterization of Extended Spectrum $\beta$-lactamases (ESBL) and integrons genes.

\section{Methods}

This study was carried out from August 2013 to October 2015 and involved 31 DEC strains isolated from diarrheal stools samples collected from children less than five years of age. The identification and characterization of DEC strains was done through the standard biochemical tests those were confirmed using API $20 \mathrm{E}$ and Polymerase Chain Reaction (PCR). The determination of antimicrobial resistance was realized by the disk diffusion method then an amplification of the $\beta$-lactamase resistance genes and integrons by PCR was done.

\section{Results}

Out of the 419 E. coli strains identified, 31 isolates (7.4\%) harbored the DEC virulence genes. From these DEC, 21 (67.7\%) were ESBL-producing E. coli. Susceptibility to ESBL-producing E. coli showed that the majority of isolates were highly resistant to amoxicillin (77.4\%), amoxicillin clavulanic acid (77.4\%) and piperacillin (64.5\%). The following antibiotic resistance genes and integron were identified from the $31 \mathrm{DEC}$ isolates: $b / a_{\mathrm{TEM}}(6.5 \%), b / a_{\mathrm{SHV}}(19.4 \%), b / a_{\mathrm{OXA}}$ (38.7\%) bla CTX-M $(9.7 \%)$, Int1 (58.1\%) and Int3 (19.4\%). No class 2 integrons (Int2) was characterized.

\section{Conclusions}

Because of the high prevalence of multidrug-resistant ESBL organisms found in this study among pediatric patients, there is a need of stringent pediatric infection control measures.

\section{Background}

Antimicrobial resistance (AMR) is one of the most serious global public health threats in this century which is especially urgent regarding antibiotic resistance in bacteria [1], particularly in Enterobacterales [2]. This phenomenon has arisen globally in both nosocomial and community settings as a consequence of widespread antibiotics' consumption [3]. Enterobacterales are a large order of different types of bacteria including Escherichia colithat commonly cause infections both in healthcare settings and in communities [4]. To survive the effects of antibiotics, some Enterobacterales can produce enzymes called extended-spectrum beta-lactamases (ESBLs) that break down and destroy some commonly used antibiotics, including penicillins and cephalosporins, and make these drugs ineffective for treating infections [4]. Over the last decade, many studies have reported the presence of Extended Spectrum $\beta$-lactamases (ESBL)-mediated resistance in Gram negative bacteria causing infections in patients [5-9]. Infections that can be caused by ESBL-producing bacteria include urinary tract infection (UTI), diarrhea, skin infections and pneumonia [10]. Possible medications used to treat ESBL infection include carbapenems, which are useful against infections caused by E. coli or Klebsiella pneumoniae bacteria, fosfomycin, beta-lactamase inhibitors, nonbeta-lactam antibiotics and colistin when other medications have failed to stop the ESBL infection [10]. Unfortunately, the excessive use of antibiotics, in particular $\beta$ - lactams, leads to the selection of ESBL producing strains [11]. Because of the emergence and distribution of Multidrug Resistant (MDR) E. coli is complicating the treatment of various serious infections $[12,13]$, the World Health Organization (WHO) has long recognised the need for an improved and coordinated global effort to contain AMR [1]. The burden of AMR, including MDR, varies between the regions; however, low and middle-income countries share a disproportionate burden due to multitude of factors embedded in the characteristics of the health system, policy, and the practice [14].

In Burkina Faso, there is an emergence of $\beta$-lactam resistant enterobacteria, both in rural and urban areas [9, 15-17]. Otherwise, carbapenemase-encoding genes are widespread in many parts of the world [18]. According to a previous study, carbapenemase-producing Enterobacterales (CPE) remain one of the most urgent healthcare threats [2].

To this day, the ESBLs and integrons' genes have been poorly characterized in Burkina Faso, particularly in enteric bacteria in children less than five years of age. However, it is imperative that bacterial isolates from underdeveloped regions undergo extensive MDR characterization to inform national strategies designed to halt the continuing spread of these dangerous pathogens [19]. Therefore, the aim of this study was to determine the resistance of diarrheagenic Escherichia coli strains to $\beta$-lactams antibiotics and perform the molecular characterization of Extended Spectrum $\beta$-lactamases (ESBL) and integrons genes among clinical DEC isolated from stools collected in children less than five years of age.

\section{Methods}

\section{Study design, area, and sample population}

It is a cross-sectional study conducted in two hospitals of Ouagadougou, Burkina Faso (Paul VI and Schiphra) during August 2014 to October 2015 (Fig. 1). The Paul VI hospital is located in peripheral area and the Schiphra's hospital in the city center at the dam edge of Ouagadougou. Many patients from Ouagadougou and its surroundings attend these two health care centers because of the good level of health care. The study population comprised children below 5 years attending the hospital for treatment. 
The specimens were collected adhering to a standard protocol from pediatric patients below 5 years of age with acute diarrhea and who were hospitalized or visited the health centers as outpatient. Thus, children who attended the hospitals for treatment and provided assent (from parents) or consent for the study were included in the study. Any child over the age of 5 years was excluded from the study.

\section{Sample collection and transport}

Three hundred and fifteen (315) stool samples were collected in sterile containers and transported to the laboratory of molecular biology, epidemiology and surveillance of bacteria and viruses transmitted by food, centre for research in biological, food and nutritional sciences at the Joseph KI-ZERBO University of Ouagadougou within $24 \mathrm{~h}$ in a cool box at $+4^{\circ} \mathrm{C}$ for immediate analysis.

\section{Bacterial isolates}

Isolation of E. coli was carried out onto eosin methylene blue agar (Liofilchem, Italy) and the plates were incubated at $+37^{\circ} \mathrm{C}$ for $18-24 \mathrm{~h}$. After this stage, the suspected $E$. coli colonies were selected and streaked onto Mueller-Hinton agar plate (Liofilchem, Italy). Confirmation was carried out by a biochemical microbiology method based on negative urease (Bio-Rad, France), negative citrate (Liofilchem, Italy), positive indole (Bio-Rad, France), positive lactose

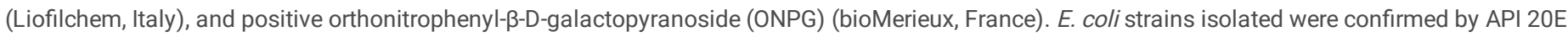
(bioMérieux, France).

The five main pathogroups of E. coli (Enteroaggregative E. coli:EAEC, Enteropathogenic E. coli: EPEC, Enteroinvasive E. coli: EIEC, Enterohemorrhagic E. coli: EHEC and Enterotoxigenic E. coli: ETEC) were characterized by the16-plex PCRas described by Antikainen et al. [20].

\section{Antimicrobial susceptibility testing}

All identified isolates of $E$ coli were treated for susceptibility testing against amoxicillin $(25 \mu \mathrm{g})$, amoxicillin-clavulanic acid $(20 / 10 \mu \mathrm{g})$, ceftriaxone $(30 \mu \mathrm{g})$, cefotaxime $(30 \mu \mathrm{g})$, cefepime $(30 \mu \mathrm{g})$, cefixime $(10 \mu \mathrm{g})$, piperacillin $(75 \mu \mathrm{g})$, piperacillin-tazobactam $(100+10 \mu \mathrm{g})$, imipenem $(10 \mu \mathrm{g})$ and aztreonam $(30 \mu \mathrm{g})$ (Bio-Rad, France) following disc diffusion method on Mueller-Hinton Agar (Liofilchem, Italy). Results were interpreted based on the European Committee of Antimicrobial Susceptibility Testing (EUCAST) guidelines [21]. These isolates which were not susceptible (either resistant or intermediate) to 3 or more antibiotics classes were considered as MDR [22].

\section{Screening and confirmation of ESBL and integrons producers}

A double synergy test was used for ESBL-producing strains testing. This consisted of placing discs (2-3 cm diameter) of ceftriaxone and cefotaxime around an amoxicillin-clavulanic acid disc on the bacterial plate.

For molecular characterization, DNA extraction was performed using heating method [23]. A loopful of bacterial growth from Mueller-Hinton agar (Liofilchem, Italy) plate was suspended in $1 \mathrm{ml}$ of sterilized water. The mixture was boiled for $10 \mathrm{~min}$ at $+100^{\circ} \mathrm{C}$ and centrifuged for $10 \mathrm{~min}$ at $12000 \mathrm{rpm}$ at $+4^{\circ} \mathrm{C}$. Supernatant was then collected and used for the PCR reactions as DNA matrices. Multiplex PCR assays were performed for detecting EBLS-encoding genes (bla $a_{\mathrm{TEM}}, b / a_{\mathrm{SHV}}, b l a_{\mathrm{OXA}}$ and $b / a_{\mathrm{CTX}-\mathrm{M}}$ ) and the presence of the class 1, class 2 , class 3 integrons from the $\beta$-lactams resistant DEC strains. Primers (GeneCust, France) used for these amplifications are described in Table 1.

Table 1

List of all primers used for antibiotic ESBL genes and integrons detection

\begin{tabular}{|c|c|c|c|}
\hline Genetic resistance supports & Genes & Primers sequence ( $\left(5^{\prime}\right.$ to 3 ') & Product size (bp) \\
\hline \multirow[t]{8}{*}{$\beta$-Lactams resistance gene } & \multirow[t]{2}{*}{$b l a_{\mathrm{TEM}}$} & F: ATG AGT ATT CAA CAT TTC CG & \multirow[t]{2}{*}{1080} \\
\hline & & R: CCA ATG CTT ATT CAG TGA GG & \\
\hline & \multirow[t]{2}{*}{$b l a_{\mathrm{SHV}}$} & F : TTA TCT CCC TGT TAG CCA CC & \multirow[t]{2}{*}{768} \\
\hline & & R: GAT TTG CTG ATT TCG CTC GG & \\
\hline & \multirow[t]{2}{*}{$b l a_{\mathrm{OXA}}$} & F: ATG AAA AAC ACA ATA CAT ATC & \multirow[t]{2}{*}{813} \\
\hline & & R: AAT TTA GTG TGT TTA GAA TGG & \\
\hline & \multirow[t]{2}{*}{ bla $_{C T X-M}$} & F: -ATG TGC AGY ACC AGT AAR GT & \multirow[t]{2}{*}{544} \\
\hline & & R: -TGG GTR AAR TAR GTS ACC AGA & \\
\hline \multirow[t]{6}{*}{ Integrons } & \multirow[t]{2}{*}{ Int1 } & F: ATT TCT GTC CTG GCT GGC GA & \multirow[t]{2}{*}{600} \\
\hline & & R: ACA TGT GAT GGC GAC GCA CGA & \\
\hline & \multirow[t]{2}{*}{ Int2 } & F: CAC GGA TAT GCG ACA AAA AGG T & \multirow[t]{2}{*}{806} \\
\hline & & R: GTA GCA AAC GAC TGA CGA AAT G & \\
\hline & \multirow[t]{2}{*}{ Int3 } & F: GCC CCG GCA GCG ACT TTC AG & \multirow[t]{2}{*}{600} \\
\hline & & R: ACG GCT CTG CCA AAC CTG ACT & \\
\hline
\end{tabular}

Thermocycling conditions were as follows: $5 \mathrm{~min}$ at $+94^{\circ} \mathrm{C}$, followed by 35 amplification cycles of $+94^{\circ} \mathrm{C}$ for $30 \mathrm{~s}, 59 \pm 4^{\circ} \mathrm{C}$ for $60 \mathrm{~s}$ and $+72^{\circ} \mathrm{C}$ for $60 \mathrm{~s}$ with a final extension of $+72^{\circ} \mathrm{C}$ for $10 \mathrm{~min}$ on a thermal cycler (Gene Amp 9700, Applied Biosystems). PCR products were revealed on $1.5 \%$ stained Redsaf agarose 
gel (Prolabo, France), after electrophoresis.under UV light (Gel Logic 200).

The PCR assays were carried out in a $25 \mathrm{ml}$ reaction mixture, which consisted of $2.5 \mu \mathrm{l}$ of the supernatant added to $22.5 \mu \mathrm{l}$ reaction mixture. This mixture contained $5 \mathrm{U}$ of Taq DNA polymerase (Accu Power, South Korea), deoxyribonucleic triphosphate (10 mM), buffer GC (10X), MgCl2 (25 mM) and PCR primers $(10 \mu \mathrm{M})$. Thermocycling conditions were as follows: $5 \mathrm{~min}$ at $+94^{\circ} \mathrm{C}$, followed by 35 amplification cycles at $+94^{\circ} \mathrm{C}$ for $30 \mathrm{~s},+59 \pm 4^{\circ} \mathrm{C}$ for $60 \mathrm{~s}$ and $+72^{\circ} \mathrm{C}$ for $60 \mathrm{~s}$ with a final extension of $+72^{\circ} \mathrm{C}$ for $10 \mathrm{~min}$ on a thermal cycler (AB Applied Biosystems). Following PCR, the reaction products were separated using electrophoresis in 1.5\% agarose gel (weight/volume), stained with Redsaf solution (Prolabo, France) and visualized under UV light (Gel Logic 200) [23].

\section{Statistical analysis}

The Fisher's exact test with two-tailed $p$ of Open Epi version 7.1.2.0 was used to determine the statistical significance of the results. A $p$ value of $<0.05$ was considered statistically significant.

\section{Results}

\section{Prevalence of bacterial isolates}

From 315 children with diarrhea, 192 stool samples were positive to one suspected $E$. coli detection (60.9\%). Four hundred and nineteen (419) strains of $E$. coli were isolated, from which 31 DEC (7.4\%) were characterized. From these DEC, twenty-on (21) DEC were ESBL producing E. coli (67.7\%).

\section{Antimicrobial susceptibility}

All the DEC strains tested for the ten $\beta$-lactams antibiotics showed important resistances to the aminopenicillins. However, few cephalosporins and carbapenems were yet active on some pathotypes (Table 2).

Table 2

Antimicrobials susceptibility of the studied isolates to $\beta$-lactams

\begin{tabular}{|c|c|c|c|c|c|c|c|c|}
\hline \multirow[t]{2}{*}{$\begin{array}{l}\beta \text {-lactams sub- } \\
\text { families }\end{array}$} & \multirow[t]{2}{*}{ Antibiotics } & \multicolumn{2}{|c|}{$\begin{array}{l}\text { Prevalence of antibiotic susceptibility N } \\
(\%)\end{array}$} & \multicolumn{5}{|c|}{ DEC resistance prevalence $\mathrm{N}(\%)$} \\
\hline & & Resistant & Sensitive & $\begin{array}{l}\text { EPEC } \\
(n=8)\end{array}$ & $\begin{array}{l}\text { EHEC } \\
(n=3)\end{array}$ & $\begin{array}{l}\text { EIEC } \\
(n=4)\end{array}$ & $\begin{array}{l}\text { EAEC } \\
(n=15)\end{array}$ & $\begin{array}{l}\text { ETEC } \\
(n=1)\end{array}$ \\
\hline \multirow[t]{4}{*}{ Penicillins } & Amoxicillin & $24(77.4)$ & $7(22.6)$ & $6(76)$ & $\begin{array}{l}2 \\
(66.6)\end{array}$ & $\begin{array}{l}4 \\
(100)\end{array}$ & $\begin{array}{l}11 \\
(73.3)\end{array}$ & $1(100)$ \\
\hline & $\begin{array}{l}\text { Amoxicillin- clavulanic } \\
\text { acid }\end{array}$ & $24(77.4)$ & $7(22.6)$ & $6(76)$ & $\begin{array}{l}2 \\
(66.6)\end{array}$ & $\begin{array}{l}4 \\
(100)\end{array}$ & $\begin{array}{l}11 \\
(73.3)\end{array}$ & $1(100)$ \\
\hline & Piperacillin & $20(64.5)$ & $11(35.5)$ & $\begin{array}{l}5 \\
(62.5)\end{array}$ & $\begin{array}{l}2 \\
(66.6)\end{array}$ & $3(75)$ & $9(60)$ & $1(100)$ \\
\hline & Piperacillin-tazobactam & $12(38.7)$ & $19(61.3)$ & $\begin{array}{l}3 \\
(37.5)\end{array}$ & $\begin{array}{l}2 \\
(66.6)\end{array}$ & $1(25)$ & $5(33.3)$ & $1(100)$ \\
\hline \multirow[t]{4}{*}{ Cephalosporins } & Ceftriaxone & $13(41.9)$ & $18(58.1)$ & $2(25)$ & $\begin{array}{l}1 \\
(33.3)\end{array}$ & $2(50)$ & $7(46.6)$ & $1(100)$ \\
\hline & Cefixime & $13(41.9)$ & $18(58.1)$ & $2(25)$ & $\begin{array}{l}1 \\
(33.3)\end{array}$ & $2(50)$ & $7(46.6)$ & $1(100)$ \\
\hline & Cefotaxim & $14(45.2)$ & $17(54.8)$ & $2(25)$ & $\begin{array}{l}2 \\
(66.6)\end{array}$ & $2(50)$ & $7(46.6)$ & $1(100)$ \\
\hline & Cefepim & $14(45.2)$ & $17(54.8)$ & $2(25)$ & $\begin{array}{l}2 \\
(66.6)\end{array}$ & $2(50)$ & $7(46.6)$ & $1(100)$ \\
\hline Monobactam & Aztreonam & $14(45.2)$ & $17(54.8)$ & $2(25)$ & $\begin{array}{l}2 \\
(66.6)\end{array}$ & $2(50)$ & $7(46.6)$ & $1(100)$ \\
\hline Carbapenems & Imipenem & $5(16.1)$ & $26(83.9)$ & $\begin{array}{l}1 \\
(12.5)\end{array}$ & $\begin{array}{l}1 \\
(33.3)\end{array}$ & $0(0)$ & $3(20)$ & $0(0)$ \\
\hline
\end{tabular}

\section{Correlation between resistance phenotype and resistance genetic supports}

Nineteen (19) out of the 21 ESBLs producing E. coli (90.5\%), had ESBLs genes. The following resistance genes were characterized: $12 \mathrm{~b} / a_{0 X A}(38.7 \%), 6$ bla $a_{\text {SHV }}$ (19.4\%), 3 bla $a_{\text {CTX-M }}(9.7 \%)$ and 2 bla $a_{\text {TEM }}(6.5 \%)$. Our results showed that the genes responsible for the production of bla $a_{0 X A} \beta$-lactamases $12 / 31$ (38.7\%) were more prevalent in comparison to the genes encoding bla $a_{\mathrm{TEM}}, b / a_{\mathrm{SHV}}$ and bla $a_{\mathrm{CTX}-\mathrm{M}} \beta$-lactamases (Table 3 ). From the three classes of integrons (Int1, Int2 and Int3) assessed among the resistant strains carrying ESBL genes, only 18 Int1 (58.1\%) and 2 Int3 (19.4\%) was detected. The class 3 integron was detected in only EIEC. No class 2 integrons (Int2) were characterized from the resistant strains. The coexistence of the three resistance genes $\left(b / a_{\mathrm{SHV}}, b / a_{\mathrm{OXA}}, b / a_{\mathrm{CTX}-\mathrm{M}}\right)$ and Int 1 was found in one EHEC (Table 3). The bla OXA gene (Fig. 2) was associated with Int1 (Fig. 3) in 11 cases $(p=0.001)$ while the bla SHV $_{\text {gene was }}$ associated with Int1 in 5 cases $(p=0.100)$. 
Table 3

Correlation between E. coli pathotypes, antibiotics resistance and genetic resistance supports

\begin{tabular}{|c|c|c|c|c|c|c|c|c|c|c|c|c|c|c|c|c|}
\hline \multirow{3}{*}{$\begin{array}{l}\text { DEC } \\
\text { strains }\end{array}$} & \multirow{3}{*}{$\begin{array}{l}\text { Resistance } \\
\text { phenotypes }\end{array}$} & \multicolumn{10}{|c|}{ Antibiotics } & \multicolumn{5}{|c|}{ Genetic resistance supports } \\
\hline & & \multirow[b]{2}{*}{ AMC } & \multirow[b]{2}{*}{ AMX } & \multirow[b]{2}{*}{ CTX } & \multirow[b]{2}{*}{ ATM } & \multirow[b]{2}{*}{ IPM } & \multirow[b]{2}{*}{ CRO } & \multirow[b]{2}{*}{ FEP } & \multirow[b]{2}{*}{ CFM } & \multirow[b]{2}{*}{ TZP } & \multirow[b]{2}{*}{ PIP } & \multicolumn{4}{|c|}{ Resistance genes } & \multirow{2}{*}{$\begin{array}{l}\text { Integro } \\
\text { Int/1 }\end{array}$} \\
\hline & & & & & & & & & & & & bla & $b^{\prime} a_{\mathrm{SHV}}$ & $b^{b} a_{O X A}$ & $b / a_{\mathrm{CTX}-\mathrm{M}}$ & \\
\hline \multicolumn{17}{|c|}{$\begin{array}{l}\text { Schiphra's hospital }(n= \\
9 / 18 ; 50 \%)\end{array}$} \\
\hline EHEC & $\begin{array}{l}\text { ESBL, } \\
\text { Carbapenemase }\end{array}$ & $\mathrm{R}$ & $\mathrm{R}$ & $\mathrm{R}$ & $\mathrm{R}$ & $\mathrm{R}$ & - & $\mathrm{R}$ & - & $\mathrm{R}$ & $\mathrm{R}$ & - & + & + & + & + \\
\hline aEPEC & ESBL & $\mathrm{R}$ & $\mathrm{R}$ & - & - & - & - & - & - & - & - & + & - & - & - & + \\
\hline tEPEC & ESBL & $\mathrm{R}$ & $\mathrm{R}$ & $\mathrm{R}$ & $\mathrm{R}$ & - & $\mathrm{R}$ & $\mathrm{R}$ & $\mathrm{R}$ & $\mathrm{R}$ & $\mathrm{R}$ & - & - & + & - & + \\
\hline tEPEC & ESBL & $\mathrm{R}$ & $\mathrm{R}$ & - & - & - & - & - & - & $\mathrm{R}$ & $\mathrm{R}$ & - & + & - & - & + \\
\hline EIEC & ESBL & $\mathrm{R}$ & $\mathrm{R}$ & - & - & - & - & - & - & - & $\mathrm{R}$ & - & + & - & - & + \\
\hline EAEC & ESBL & $\mathrm{R}$ & $\mathrm{R}$ & - & - & - & - & - & - & - & $\mathrm{R}$ & - & + & - & - & + \\
\hline EAEC & ESBL & $\mathrm{R}$ & $\mathrm{R}$ & - & - & - & - & - & - & - & - & - & + & - & - & + \\
\hline EAEC & $\begin{array}{l}\text { ESBL, } \\
\text { Carbapenemase }\end{array}$ & $\mathrm{R}$ & $\mathrm{R}$ & $\mathrm{R}$ & $\mathrm{R}$ & $\mathrm{R}$ & $\mathrm{R}$ & $\mathrm{R}$ & $\mathrm{R}$ & $\mathrm{R}$ & $\mathrm{R}$ & - & - & - & + & + \\
\hline EAEC & ESBL & $\mathrm{R}$ & $\mathrm{R}$ & $\mathrm{R}$ & $\mathrm{R}$ & - & $\mathrm{R}$ & $\mathrm{R}$ & $\mathrm{R}$ & $\mathrm{R}$ & $\mathrm{R}$ & - & - & + & - & + \\
\hline \multicolumn{17}{|c|}{$\begin{array}{l}\text { Paul VI hospital }(n= \\
10 / 13 ; 76.9 \%)\end{array}$} \\
\hline aEPEC & ESBL, PHN & $\mathrm{R}$ & $\mathrm{R}$ & - & - & - & - & - & - & - & $\mathrm{R}$ & - & - & + & - & + \\
\hline aEPEC & $\begin{array}{l}\text { ESBL, } \\
\text { Carbapenemase }\end{array}$ & $\mathrm{R}$ & $\mathrm{R}$ & $\mathrm{R}$ & $\mathrm{R}$ & $\mathrm{R}$ & $\mathrm{R}$ & $\mathrm{R}$ & $\mathrm{R}$ & $\mathrm{R}$ & $\mathrm{R}$ & - & - & + & - & + \\
\hline aEPEC & ESBL, PHN & $\mathrm{R}$ & $\mathrm{R}$ & - & - & - & - & - & - & - & $\mathrm{R}$ & - & - & + & - & + \\
\hline EIEC & ESBL, PHN & $\mathrm{R}$ & $\mathrm{R}$ & $\mathrm{R}$ & $\mathrm{R}$ & - & $\mathrm{R}$ & $\mathrm{R}$ & $\mathrm{R}$ & $\mathrm{R}$ & $\mathrm{R}$ & - & + & + & - & - \\
\hline EAEC & ESBL, PHN & $\mathrm{R}$ & $\mathrm{R}$ & - & - & - & - & - & - & - & $\mathrm{R}$ & - & - & + & - & + \\
\hline ETEC & CASE, PHN & $\mathrm{R}$ & $\mathrm{R}$ & $\mathrm{R}$ & $\mathrm{R}$ & - & $\mathrm{R}$ & $\mathrm{R}$ & $\mathrm{R}$ & $\mathrm{R}$ & $\mathrm{R}$ & - & - & + & - & + \\
\hline EAEC & ESBL, PHN & $\mathrm{R}$ & $\mathrm{R}$ & - & - & - & - & - & - & - & $\mathrm{R}$ & - & - & + & - & + \\
\hline EAEC & ESBL, PBN & $\mathrm{R}$ & $\mathrm{R}$ & $\mathrm{R}$ & $\mathrm{R}$ & - & $\mathrm{R}$ & $\mathrm{R}$ & $\mathrm{R}$ & - & $S$ & + & - & - & - & + \\
\hline EAEC & $\begin{array}{l}\text { ESBL, } \\
\text { Carbapenemase }\end{array}$ & $\mathrm{R}$ & $\mathrm{R}$ & $\mathrm{R}$ & $\mathrm{R}$ & $\mathrm{R}$ & $\mathrm{R}$ & $\mathrm{R}$ & $\mathrm{R}$ & $\mathrm{R}$ & $\mathrm{R}$ & - & - & + & + & + \\
\hline EAEC & ESBL & $\mathrm{R}$ & $\mathrm{R}$ & $\mathrm{R}$ & $\mathrm{R}$ & - & $\mathrm{R}$ & $\mathrm{R}$ & $\mathrm{R}$ & - & - & - & - & + & - & + \\
\hline
\end{tabular}

$\mathrm{EAEC}=$ Enteroaggregative E. coli, aEPEC = Atypical Enteropathogenic E. coli, tEPEC $=$ Typical Enteropathogenic E. coli, EIEC = Enteroinvasive E. coli, EHEC = Enterohemorrhagic E. coli, ETEC = Enterotoxigenic E. coli, PHN = High-level penicillinases, $\mathrm{CASE}=$ Cephalosporinases, ESBL $=$ Extended $\mathrm{Spectrum} \beta$ lactamases, $\mathrm{AMC}=$ Amoxicillin-Clavulanic Acid, AMX = Amoxicillin, $\mathrm{CTX}=$ Cefotaxime, ATM = Aztreonam, IPM = Imipenem, CRO = Ceftriaxone, FEP = Cefepime, CFM = Cefixime, TZP = Piperacillin-tazobactam, PIP = Piperacillin, $\mathrm{R}=$ Resistant, $-=$ Absence,$+=$ Presence .

\section{Discussion}

The emergence and spread of Multidrug Resistant (MDR) bacteria are major public health threats world-wide. Particularly, DEC that produce ESBL are of great concern because their resistance to penicillins and narrow extended-spectrum cephalosporins reduces considerably the treatment options. The prevalence of ESBL in Enterobacteriaceae has been detected at local levels in various african countries; moreover, a study was conducted in 2014 on the prevalence of ESBL and what type of genes are involved in its occurrence [24]. The frequency of ESBL-producing E. coli was $67.7 \%$ in our study. Similar prevalence was reported in Egypt (69.6\%) [25] and in Palestine (66.7\%) [26]. Nevertheless, our prevalence was higher than those in Burkina Faso (58\%) [6], Iran (40.8\%) [27], Saudi Arabia (30.6\%) [28], Japan (20.4\%) [29], Colombia (11.7\%) [30] and Nepal (22.7\%) [31]. Otherwise, our result is lower than the ESBL production in clinical isolates of $E$. coli reported somewhere else in Iran [32]. The prevalence of ESBL resistance in E. coli isolates in European countries is reported to be around 3.9\% with variations between countries [33]. Overall, these percentages are lower than those found in middle income countries like Thailand (71.25\%) [34] and China (50.5\%) [35]. This difference between ESBLs prevalence's might be due to patient's age, the type of samples, the country health facilities in the management of diarrheal infections regarding antibiotics use. Indeed, in developing countries, most patients received antibiotics treatment without prescription [36, 37]; such common practices in nearly all developing countries cause a selective pressure on $E$. coli, whereas in more developed countries effective strategies for the control of antimicrobial are present, which effectively prevents the emergence of ESBLs [36]. 
It has been reported that bacteria such as E. coli and $K$. pneumoniae are major ESBL producers resulting in serious threat to the treatment regimen [38]. Indeed, ESBL enzymes are becoming increasingly expressed by many strains of pathogenic bacteria presenting diagnostic challenges to the clinical microbiology laboratories [39, 40]. Until recently, antimicrobial therapy has played an important role in the treatment of human bacterial infections. However, the drug resistance has emerged in the treatment of bacterial infections due to ESBL enzymes [39]. Indeed, this enzymes can degrade all $\beta$-lactam antibiotics leading to multi drug resistant bacteria. Therefore, reporting of ESBL-producing isolates from clinical samples is critical for the clinicians. It constitutes the guidelines to select appropriate antibiotics for the treatment, including to take proper precaution to prevent the spread of these resistant organisms to other patients [31].

The present study shows 19 ESBLs genes (90.5\%) out of the 21 ESBLs producing $E$. coli. Analysis of the ESBL-encoding genes indicated that the majority of the ESBL-positive isolates harbored bla $a_{\mathrm{OXA}}(38.7 \%)$, followed by bla $a_{\mathrm{SHV}}(19.4 \%)$, bla $a_{\mathrm{CTX}-\mathrm{M}}(9.7 \%)$ and $b l a_{\mathrm{TEM}}(6.5 \%)$. The emergence of $\beta-l a c t a m$ resistance in Enterobacteriaceae is related primarily to the production of enzymes such as TEM and SHV variant which were the most common ESBLs during the past decade. However, OXA and CTX-M $\beta$-lactamases have emerged as prevalent ESBL worldwide type compared to the TEM and SHV genotypes [41].

In the present study, OXA-type ESBL producing DEC strains (38.7\%) was the most frequently detected ESBL gene. This prevalence is lower than that reported in our previous study in rural area of Burkina Faso: $100 \%$ [9], also lower comparatively to $52 \%$ reported in Pakistan [42]. However, a recent study in young children reported $3 \%$ of commensal E. coli bearing the bla $a_{0 X A}$ gene in Bangladesh [41]. Thus, it appears that the emergence of ESBLs producing bacteria among gut bacteria of young children can transfer resistance and related genes horizontally across pathogenic $E$. coli and commensal $E$. coli leading to a public health concern. Most of the OXA-type ESBL producing E. coli isolates (29\%) in our study were detected from the Paul VI hospital ( $p=0.002)$. This hospital is located in peripheral area of Ouagadougou and most of the people living in the slums with poor sanitation conditions attend it for health care sought. Moreover, the provision of confessional care has less difficult accessibility for the peripheral neighborhoods and the population with low socio-economic level. Otherwise, people in Burkina Faso do not consult a health care agent in the case of diseases such as gastrointestinal infections and use self-medication instead [37]. Our results showed $19.4 \%$ of SHV-type ESBL producing E. coli which is a little similar to $21 \%$ detected in Pakistan [42]. By cons, this prevalence is higher than $0 \%$ [9] and 5.9\% [17], previously reported in Burkina Faso but lower than 45\% reported in Iran [27]. The bla isolates while its prevalence was $25 \%$ in our earlier report [9] and $40.1 \%$ by a study conducted in Enterobacteriaceae from Burkinabe patients [17]. Moreover, few studies from other parts of world have shown different prevalence of bla ${ }_{\text {CTX-M }}$ gene among isolates including $98.8 \%$ (China), 84.7\% (Chile), $13.6 \%$ (Tanzania), 76\% (Pakistan), 97.8\% (Chad) and 81.6\% (Egypt) [25, 42-46]. Indeed, CTX-M b-lactamases are recognized as the most widespread extendedspectrum b-lactamases (ESBLs) among clinical isolates of Enterobacteriaceae [47]. Besides, an earlier report from Nigeria has shown the predominance of CTX-M15 in wild birds and cattle in Nigeria [48] suggesting that this gene could be transferred to humans by animals. Finally, our study revealed $6.5 \%$ of TEM-

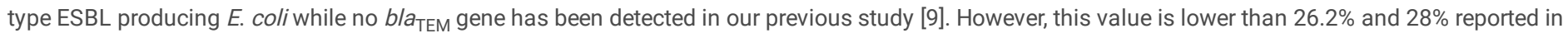
Burkina Faso and Pakistan, respectively $[17,42]$. The resistance to amoxicillin/amoxicillin clavulanic acid observed in the two E. coli strains (6.5\%) may be mainly mediated by the production of these plasmid-encoded TEM enzymes.

Among the three class of integron, class 1 integron (58.1\%) was majority characterized from the resistant strains in accordance with $56 \%$ reported in Bangladesh [41]. This result confirms those of previous studies which showed that class 1 integrons was predominantly represented in Enterobacteriaceae $[49,50]$. However, a previous report in Burkina Faso has shown a lower prevalence (44.4\%) of Int1 [51]. On the other hand, studies reported a high prevalence of Int1 (80\%) in E. coli isolated from dairy products consumed in Burkina Faso [52] and in human, animal, and food in Spain [53]. This could increase the risk of emergence and spread of MDR E. coli, since humans are always in contact with these different ecosystems, especially when there is a lack of food hygiene and sanitation. Moreover, class 1 integrons can facilitate the spread of antibiotic-resistance genes meaning that it could have public health consequences [54].

The class 3 integrons was detected in only EIEC. No class 2 integrons (Int2) was characterized from the resistant strains. By cons, $22.2 \%$ of Int2 was detected in our previous study [51]. Moreover, a study also found the presence of Int2 gene in Senegalese Shigella spp isolates [49].

Two strains of EIEC harbored both class 1 and 3 integrons. However, a previous study showed that E. coli harbored class 1 and 2 integrons simultaneously [50]. Otherwise, in the present study, one EIEC strain was resistant to aztreonam, imipenem and possess ESBL-carbapenemase phenotype. This strain was resistant to all sub-families (penicillins, cephalosporins, monobactam and carbapenems) of $\beta$-lactams antibiotic tested and also showed simultaneous presence of bla $a_{\mathrm{SHV}}, b / a_{\mathrm{OXA}}, b / a_{\mathrm{CTX}-\mathrm{M}}$ and Int1. Indeed, strains that had this aztreonam-resistant phenotype possessed both the resistance gene [27]. Resistance to this antibiotic could be explained by genetic mutations [43]. It has been described that the coexistence of these two classes of integrons [42] and/or several

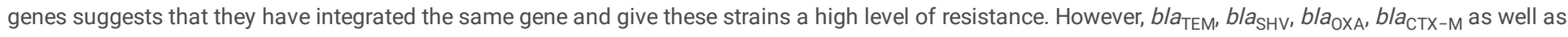
integrons (Int1, Int2 and Int3) are involved in the antibiotic resistance of DEC, but the presence of resistant strains producing ESBL and lacking ESBL gene $\left(b / a_{\mathrm{TEM}}, b / a_{\mathrm{SHV}}, b / a_{\mathrm{OXA}}\right.$ and $b / a_{\mathrm{CTX}-\mathrm{M})}$ and integron suggests that there are other mechanisms for the dissemination of antibiotic resistance in DEC strains.

\section{Conclusions}

This study highlights the important involvement of genes and integrons into multidrug resistance strains of $E$. coli in two main hospitals of Ouagadougou. The most important finding was the detection of four $E$. coli multiresistant strains producing ESBL that were resistant to imipenem, aztreonam and harbored class 1 integrons. Another important observation was the detection of two E. coli multiresistant strains producing ESBL but lacking a resistance gene and/or integrons. Our results have demonstrated the emergence and dissemination of multidrug resistant $E$. coli strains hosting several genes responsible for the production of ESBL in clinical isolates. Ultimately, to fight effectively against the emergence of antimicrobial resistance, an integrated surveillance network should be set up, which would be of great benefit to national antimicrobial resistance control programs.

\section{List Of Abbreviations}

DEC 
Diarrheagenic Escherichia coli; ESBL:Extended Spectrum ß-lactamases; API:Analytical Profile Index; MDR:Multi Drug Resistant; EUCAST:European Committee on Antimicrobial Susceptibility Testing.

\section{Declarations}

\section{Ethics approval and consent to participate}

Permission to conduct this study was obtained from the hospital authorities of Burkina Faso and informed verbal consent was obtained from the parents of every child before samples collection. The study protocol was approved by the Ethical Committee of Burkina Faso ( $\left.{ }^{\circ} 2009-39\right)$.

\section{Consent for publication}

Not applicable.

\section{Availability of data and materials}

Not applicable.

\section{Competing interests}

The authors declare that they have no competing interests.

\section{Funding}

Not applicable.

\section{Authors' contributions}

RD was responsible for initiation of the study and data analysis. Laboratory investigations were performed by RD and AK under the guidance of IS, AST, AGS and NB. NO, OT, WADK, AST, NKG, AGS and NB participated in data analysis and preparation of the manuscript. All authors have read and approved the final manuscript.

\section{Acknowledgments}

The authors gratefully thank “Réseau de Recherche sur les Maladies Entériques à potentiel épidémique en Afrique de l'Ouest (REMENTA)/Programme d’Appui à la Recherche en Réseau en Afrique (PARRAF)"for technical support. We also thank the parents and guardians of children as well as the authorities of the Paul VI and Schiphra's hospitals for their honest cooperation.

\section{References}

1. Prestinaci F, Pezzotti P, Pantosti A. Antimicrobial resistance: a global multifaceted phenomenon. Pathog Glob Health. 2015;109(7):309-18.

2. Dembélé R, Soulama I, Kaboré WAD, Konaté A, Kagambèga A, Coulibaly DN'G, et al. Molecular Characterization of Carbapenemase-Producing Enterobacterales in Children with Diarrhea in Rural Burkina Faso. J. Drug Deliv. Ther. 2021;11(1) 84-92.

3. Ashley EA, Lubell Y, White NJ, Turner P. Antimicrobial Susceptibility of Bacterial Isolates from Community Acquired Infections in Sub-Saharan Africa and Asian Low and Middle Income Countries. Trop Med Int Health. 2011;16:1167-9.

4. Centers for Disease Control and Prevention, National Center for Emerging and Zoonotic Infectious Diseases (NCEZID). Division of Healthcare Quality Promotion (DHQP). Healthcare-associated Infections (HAl), Diseases and Organisms. Page last reviewed: November 22; 2019.

5. Raut S, Gokhale S, Adhikari B. Prevalence of extended spectrum beta-lactamases among E. coli and Klebsiella spp isolates in Manipal, Teaching Hospital, Pokhara, Nepal. J Microbio Infect Dis. 2015;5:69-75.

6. Ouédraogo AS, Sanou M, Kissou A, Sanou S, Solaré H, Kaboré F, et al. High prevalence of extended-spectrum $\beta$-lactamase producing Enterobacteriaceae among clinical isolates in Burkina Faso. BMC Infect Dis. 2016;16:326.

7. Nepal K, Pant ND, Neupane B, Belbase A, Baidhya R, Shrestha RK, et al. Extended spectrum beta-lactamase and metallo beta-lactamase production among Escherichia coli and Klebsiella pneumoniae isolated from different clinical samples in a tertiary care hospital in Kathmandu, Nepal. Ann Clin Microbiol Antimicrob. 2017;16:62.

8. Rai S, Pant ND, Bhandari R, Giri A, Parajuli R, Aryal M, et al. AmpC and extended spectrum beta-lactamases production among urinary isolates from a tertiary care hospital in Lalitpur, Nepal. BMC Res Notes. 2017;10:467.

9. Dembélé R, Konaté A, Traoré O, Kaboré WAD, Soulama I, Kagambèga A, et al. Extended spectrum beta-lactamase and fluoroquinolone resistance genes among Escherichia coli and Salmonella isolates from children with diarrhea, Burkina Faso. BMC Pediatr. 2020a; 20:459.

10. Jewell T, Biggers A. ESBLs (Extended Spectrum Beta-Lactamases). Updated on April 14, 2017. https://www.healthline.com/health/esbl.

11. Chang YT, Coombs G, Ling T, Balaji V, Rodrigues C, Mikamo H, et al. Epidemiology and trends in the antibiotic susceptibilities of Gram negative bacilli isolated from patients with intra-abdominal infections in the Asia-Pacific region, 2010-2013. Int J Antimicrob Agents. 2017;49:734-9.

12. Allocati N, Masulli M, Alexeyev MF, llio CD. Escherichia coli in Europe: an overview. Int J Environ Res Public Health. 2013;10:6235-54. 
13. Mariappan S, Sekar U, Kamalanathan A. Carbapenemaseproducing Enterobacteriaceae: Risk factors for infection and impact of resistance on outcomes. Int J App Basic Med Res. 2018; $7: 32$ - 9.

14. Pokharel S, Raut S, Adhikari B. Tackling antimicrobial resistance in low- and middle-income countries. BMJ Glob Health. $2019 ; 4: e 002104$.

15. Dembélé R, Bonkoungou IJO, Konaté A, Bsadjo-Tchamba G, Bawa HI, Bako E, et al. Serotyping and antibiotic resistance of Enteropathogenic Escherichia coli and E. coli 0157 isolated from diarrheal children in rural area of Burkina Faso. Afr J Microbiol Res. 2015;9:1053-9.. ; :

16. Ouédraogo A-S, Sanou S, Kissou A, Poda A, Aberkane S, Bouzinbi N, et al. Fecal Carriage of Enterobacteriaceae Producing Extended-Spectrum BetaLactamases in Hospitalized Patients and Healthy Community Volunteers in Burkina Faso. Microbial Drug Resist. 2017;23:1.

17. Kpoda DS, Ajayi A, Somda M, Traore O, Guessennd N, Ouattara AS, et al. Distribution of resistance genes encoding ESBLs in Enterobacteriaceae isolated from biological samples in health centers in Ouagadougou, Burkina Faso. BMC Res Notes. 2018;11:471.

18. Halat DH, Moubareck CA. The Current Burden of Carbapenemases: Review of Significant Properties and Dissemination among Gram-Negative Bacteria. Antibiot. 2020;9:186.

19. Margulieux KR, Srijan A, Ruekit S, Nobthai P, Poramathikul K, Pandey P, et al. Extended-spectrum $\beta$-lactamase prevalence and virulence factor characterization of enterotoxigenic Escherichia coli responsible for acute diarrhea in Nepal from 2001 to 2016. Antimicrob Resist Infect Control. 2018;7:87.

20. Antikainen J, Tarkka E, Haukka K, Siitonen A, Vaara M, Kirveskari J. New 16 plex PCR method for rapid detection of Diarrheagenic Escherichia coli directly from stool samples. European J Clin Microbiol Infect Dis. 2009;28:899-8.

21. European Committee on Antimicrobial Susceptibility Testing (EUCAST). Recommandation 2017. Éd. V.1.0 Mars. pp 1-127.https://www.eucast.org/.

22. Magiorakos AP, Srinivasan A, Carey RB, Carmeli Y, Falagas ME, Giske CG, et al. Multidrug-resistant, extensively drug-resistant and pandrug-resistant bacteria: an international expert proposal for interim standard definitions for acquired resistance. Clin Microbiol Infect. 2012;18:268-81.

23. Moyo SJ, Maselle SY, Matee MI, Langeland N, Mylvaganam H. Identification of Diarrheagenic Escherichia coli isolated from infants and children in Dar es Salaam, Tanzania. BMC Infect Dis. 2007: 1-7.

24. Storberg V. ESBL-producing Enterobacteriaceae in Africa-a non-systematic literature review of research published 2008-2012. Infection Ecol Epidemiol. $2014 ; 4: 1: 20342$

25. Mohamed ES, Khairy RMM, Abdelrahim SS. Prevalence and molecular characteristics of ESBL and AmpC $\beta$-lactamase producing Enterobacteriaceae strains isolated from UTIs in Egypt. Antimicrob Resist Infect Control. 2020;9:198.

26. Tayh G, Laham NA, Yahia HB, Sallem RB, Elottol AE, Slama KB. Extended-Spectrum $\beta$-Lactamases among Enterobacteriaceae Isolated from Urinary Tract Infections in Gaza Strip, Palestine. Bio Med Research Inter. 2019; 11 p.

27. Seyedjavadi SS, Goudarzi M, Sabzehali F. Relation between bla $\mathrm{TEM}_{\mathrm{M}}, b / a_{\mathrm{SHV}}$ and bla $\mathrm{CTX}_{\mathrm{M}} \mathrm{M}$ genes and acute urinary tract infections. J Acute Dis. 2016;5:716.

28. Hassan H, Abdalhamid B. Molecular characterization of Extended Spectrum beta-lactamase producing Enterobacteriaceae in a Saudi Arabian tertiary hospital. J Infect Dev Ctries. 2014;8:282-8.

29. Harada Y, Morinaga Y, Yamada K, Migiyama Y, Nagaoka K, Uno N, et al. Clinical and molecular epidemiology of Extended Spectrum $\beta$-lactamaseproducing Klebsiella pneumoniae and Escherichia coli in a Japanese tertiary hospital. J Med Microbiol Diagn. 2013;2:127.

30. Martinez P, Garzôn D, Mattar S. CTX-M-producing Escherichia coli and Klebsiella pneumoniae isolated from community-acquired urinary tract infections in Valledupar, Colombia. Braz J Infect Dis. 2012;16:420-5.

31. Kayastha K, Dhungel B, Karki S, Adhikari B, Banjara MR, Rijal KR, et al. Extended-Spectrum B-Lactamase-Producing Escherichia coli and Klebsiella Species in Pediatric Patients Visiting International Friendship Children's Hospital, Kathmandu, Nepal. Infect Dis: Res Treat. 2020;13:1-7.

32. Najar PS, Eslami M, Memariani M, Siadat SD. High prevalence of bla $\mathrm{CTX}_{\mathrm{M}-1}$ group Extended Spectrum $\beta$-lactamase genes in Escherichia coli isolates from Tehran. Jundishapur J Microbiol. 2013;6:e6863.

33. Ahmed MO, Clegg PD, Williams NJ, Baptiste KE, Bennett M. Antimicrobial resistance in equine faecal Escherichia coli isolates from North West England. Ann Clin Microbiol Antimicrob. 2010;9:12.

34. Luvsansharav UO, Hirai I, Niki M, Sasaki T, Makimoto K, Komalamisra C, et al. Analysis of risk factors for a high prevalence of extended-spectrum Blactamase-producing Enterobacteriaceae in asymptomatic individuals in rural Thailand. J Med Microbiol. 2011;60:619-24.

35. Li B, Sun JY, Liu QZ, Han LZ, Huang XH, Ni YX. High prevalence of CTX-M $\beta$-lactamases in faecal Escherichia coli strains from healthy humans in Fuzhou, China. Scand J Infect Dis. 2011;43:170-4.

36. Ahmed SF, Ali MMM, Mohamed ZK, Moussa TA, Klena JD. Fecal carriage of extended-spectrum $\beta$-lactamases and AmpC-producing Escherichia coli in a Libyan Community. Ann Clin Microbiol Antimicrob. 2014;13:22.

37. Dembélé R, Huovinen E, Yelbéogo D, Kuusi M, Sawadogo G, Haukka K, et al. Burden of acute gastrointestinal infections in Ouagadougou, Burkina Faso. J Microbiol Infect Dis. 2016;6:45-52.

38. Rimal U, Thapa S, Maharajan R. Prevalence of Extended spectrum beta-lactamase producing Escherichia coli and Klebsiella species from urinary specimens of children attending Friendship International Children's Hospital. Nep J Biotech. 2017;5:32-8.

39. Gupta V. An update on newer $\beta$-lactamases. Indian J Med Res. 2007;126:417-27.

40. Sharma AR, Bhatta DR, Shrestha J, Banjara MR. Antimicrobial susceptibility pattern of Escherichia coli isolated from urinary tract infected patients attending Bir Hospital. Nepal J Sci Tech. 2013;14:177-84. 
41. Monira S, Shabnam SA, Imran ASK, Sadique A, Johura FT, Rahman KZ, et al. Multi-drug resistant pathogenic bacteria in the gut of young children in Bangladesh. Gut Pathog. 2017;9:19.

42. Abrar S, UI AN, Liaqat H, Hussain S, Rasheed F, Riaz S. Distribution of blaCTX - M, blaTEM, blaSHV and blaOXA genes in Extended-spectrum Blactamaseproducing Clinical isolates: A three-year multi-center study from Lahore, Pakistan. Antimicrob Resist Infect Control. 2019;8:80.

43. Zhao D, Quan J, Liu L, Du X, Chen Y, Jiang Y, et al. High prevalence of ESBL producing Escherichia coli and Klebsiella pneumoniae in community-onset bloodstream infections in China. J Antimicrob Chemother. 2016;72(1):273-80.

44. Sonda T, Kumburu H, van Zwetselaar M, Alifrangis M, Mmbaga BT, Lund O, et al. Prevalence and risk factors for CTX-M gram-negative bacteria in hospitalized patients at a tertiary care hospital in Kilimanjaro, Tanzania. Eur J Clin Microbiol Infect Dis. 2018;37:1-10.

45. Pavez M, Troncoso C, Osses I, Salazar R, Illesca V, Reydet P, et al. High prevalence of CTX-M-1 group in ESBL-producing Enterobacteriaceae infection in intensive care units in southern Chile. Braz J Infect Dis. 2019;23(2):102-10.

46. Ouchar Mahamat O, Tidjani A, Lounnas M, Hide M, Benavides J, Somasse C, et al. Fecal carriage of extended-spectrum ßlactamase-producing Enterobacteriaceae in hospital and community settings in Chad. Antimicrob Resist Infect Control. 2019;8:169.

47. Tani BA-KZ, Decré D, Genel N, Boucherit-Otmani Z, Arlet G, Drissi M. Molecular and Epidemiological Characterization of Enterobacterial MultidrugResistant Strains in Tlemcen Hospital (Algeria) (2008-2010). Microbial Drug Resist. 2013;19:3:185-90.

48. Fashae K, Engelmann I, Monecke S, Braun DS, Ehricht R. Molecular characterisation of extended spectrum ß-lactamase producing Escherichia coli in wild birds and cattle, Ibadan, Nigeria. BMC Veter Res. 2021;17:33.

49. Gassama-Sow A, Aïdara-Kane A, Barraud O, Gatet M, Denis F, Ploy MC. High prevalence of trimethoprim-resistance cassettes in class 1 and 2 integrons in Senegalese Shigella spp isolates. J Infect Dev Ctries. 2010;4:207-12.

50. Sambe-Ba B, Seck A, Wane AA, Fall-Niang NK, Gassama-Sow A. Sensibilité aux antibiotiques et supports génétiques de la résistance des souches de Shigella flexneri isolées à Dakar de 2001 à 2010. Bull Soc Pathol Exot. 2013;106:89-94.

51. Dembélé R, Kaboré WAD, Soulama I, Konaté A, Kagambèga A, Traoré 0 , et al. Involvement of class 1 and class 2 integrons in dissemination of tet and catA1 resistance genes of Salmonella enterica from children with diarrhea in rural Burkina Faso. Afr J Biotech. 2020b;19(1):1-7.

52. Bagré TS, Sambe-Ba B, Bawa-Ibrahim H, Bsadjo-Tchamba G, Dembélé R, Wane AA, et al. Isolation and characterization of enteropathogenic and enterotoxinogenic Escherichia coli from dairy products consumed in Burkina Faso. Afr J Microbiol Res. 2017;11(13):537-45.

53. Sáenz Y, Briñas L, Domínguez E, Ruiz J, Zarazaga M, Vila J, et al. Mechanisms of resistance in multiple-antibiotic-resistant Escherichia coli strains of human, animal, and food origins. Antimicrob Agents Chemother. 2004;48:3996-01.

54. Oliveira-Pinto C, Diamantino C, Oliveira PL, Reis MP, Costa PS, Paiva MC, et al. Occurrence and characterization of class 1 integrons in Escherichia coli from healthy individuals and those with urinary infection. J Med Microbiol. 2017;66(5)::577-83.

\section{Figures}

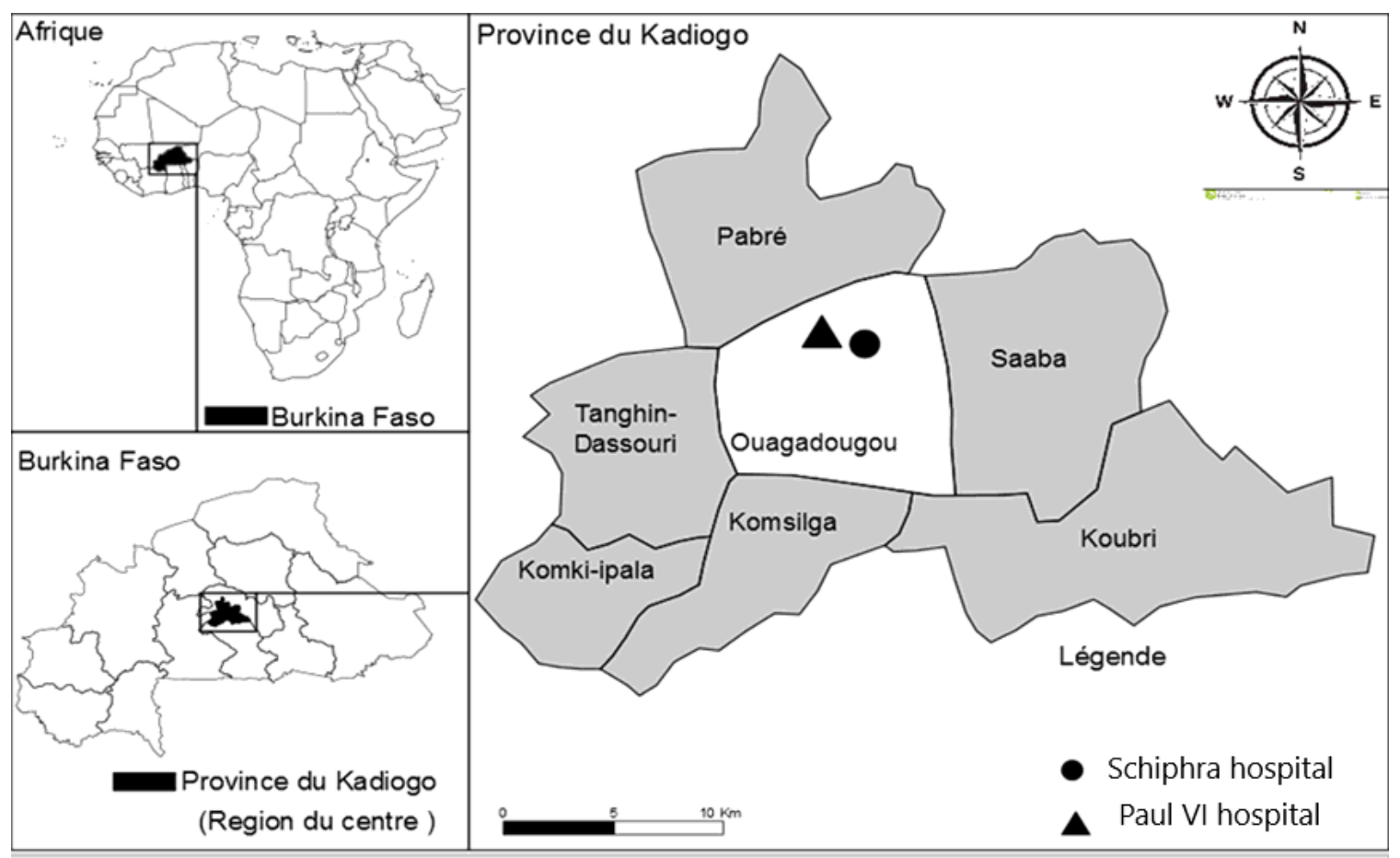

Source: BNDT DATE: 12-05-2021 REAL: René DEMBELE

Figure 1

Page $9 / 11$ 
Sampling sites in Ouagadougou Note: The designations employed and the presentation of the material on this map do not imply the expression of any opinion whatsoever on the part of Research Square concerning the legal status of any country, territory, city or area or of its authorities, or concerning the delimitation of its frontiers or boundaries. This map has been provided by the authors.

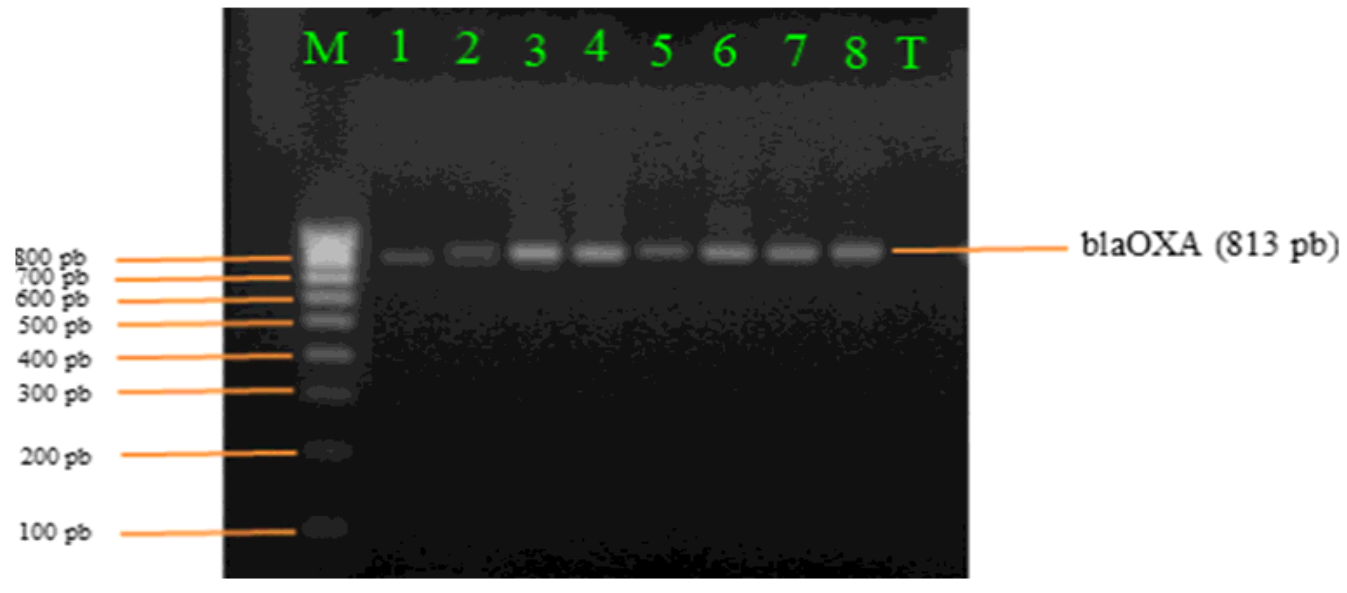

\section{Figure 2}

Agarose gel electrophoresis (1.5\%). Lane M: molecular size marker (100 bp), 1: blaOXA1 positive control (813 pb), lanes: 2-8 are positive for blaOXA gene, lane $\mathrm{T}$ : negative control.

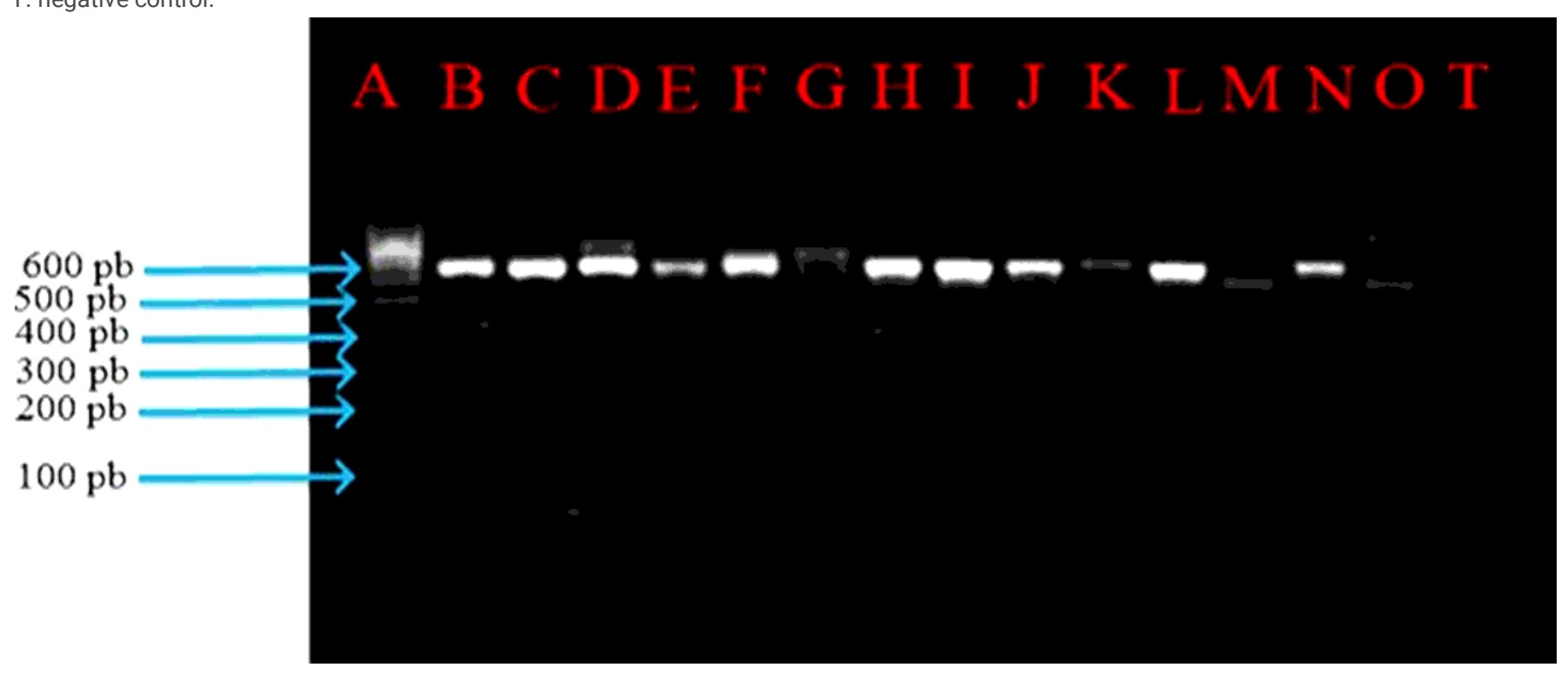

\section{Figure 3}

Agarose gel electrophoresis (1.5\%). Lane A: molecular size marker (100 bp), B: Int1 positive control (600 pb), lanes: C-0 are positive for Int1 gene, lane T: negative control. 


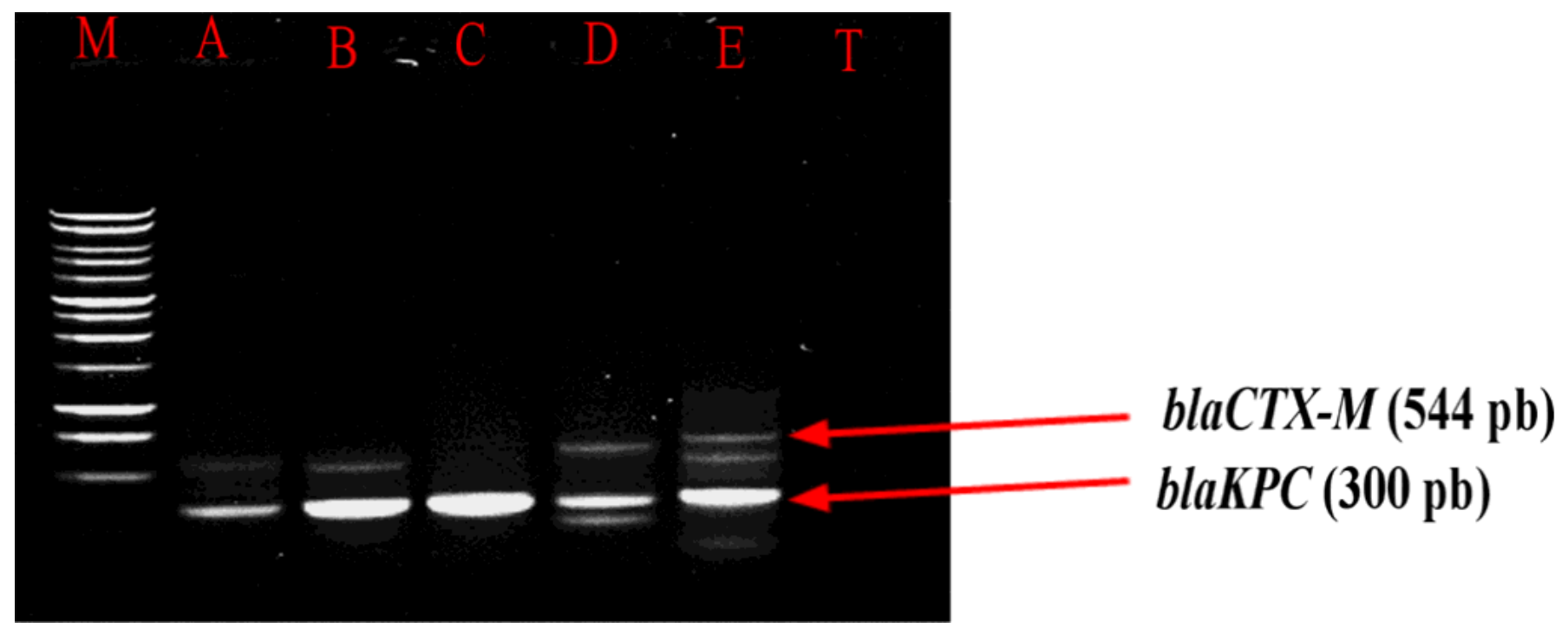

Figure 4

Agarose gel electrophoresis (1.5\%). Lane M: molecular size marker (100 bp), A: blaCTX-M positive control (544 pb), lanes: B, D and E are positive for blaCTX-M gene (544 pb), lane T: negative control. 